\title{
The Origins of Alternate Sign Languages in Australia: could they include hearing Impairment?
}

\author{
Andrew Butcher \\ Speech Pathology \& Audiology, School of Health Sciences \\ Flinders University \\ andy.butcher@flinders.edu.au
}

Keywords: sign language; Australian Aboriginal; otitis media; hearing loss

\section{Introduction}

So-called 'village' sign languages have been widely reported in the scientific literature (not to mention the mass media) (Grace, 1985; Kisch, 2004, 2008). These are (or were) found in a number of communities scattered around the world where the sign language of the deaf is also routinely used by hearing individuals. Such communities are, without exception, culturally or geographically isolated (often practising endogamy) and have a high proportion of profoundly deaf members. The deaf group develops its own sign language and the hearing members acquire mastery of it to varying degrees, using it in particular to communicate with deaf friends and relatives.

Australia appears to be unique, however, in that almost every indigenous community may have had an alternate sign language. This was understood by all the population and used by the majority - a situation which is maintained in some communities to this day. This population, while living in relatively self-contained groups for most of the year, has strong cultural connections over large areas and largely exogamous marriage practices. Factors commonly cited as contributing to the development and maintenance of these systems are both cultural (including ceremonial speech taboos - especially by women in mourning and by young males undergoing initiation - and avoidance behaviour within certain kinship relations) and practical (communicating over distance, while hunting, or with others - the profoundly deaf or the monolingual outsider - who cannot understand spoken language).

But Kendon (1988) points out "some use of signing has been recorded from many parts of Australia, including areas where extended speech taboos have not been reported" and Kwek (1991) writes "In this particular case [Punmu, Western Australia], it is hard to imagine a set of circumstances that would proscribe normal speech use to the extent of leading to the development of what appears to be a relatively complex sign system."

The proportion of the indigenous population with severe to profound deafness is somewhat higher than in the mainstream population, but a much higher proportion has a mild-to-moderate conductive hearing loss. In Australia the prevalence of severe hearing loss (60-90 dB) in males aged $15-50$ in the general population is around $1.0 \%$, whilst the prevalence of mild-to-moderate loss (20-60 dB) is around 6.7\% (Access Economics, 2006). A recent study of 134 Northern Territory (NT) Aboriginal prison inmates (Vanderpoll \& Howard, 2012) found that $9.7 \%$ of that population had a severe hearing loss $(65-90 \mathrm{~dB})$, whereas $85 \%$ had a mild-to-moderate loss (25-65 dB). This widespread hearing loss has been largely ignored as a potential factor in the development of Australian indigenous signing. 


\section{The Uniqueness of Australian Indigenous Sign Languages}

If we look at instances of hearing people using sign in communities across the world, a pattern emerges. Undoubtedly, one of the best known of such communities was Martha's Vineyard in the United States (Grace, 1985), where in the 1880 census the frequency of deafness was as high as 1 in 155 (compared to a national average of 1 in almost 6000). In the Chilmark town of Squibnocket the incidence was as high as 1 in 4 and incomers were obliged to learn the sign language in order to live in the community. In the 20th century as off-island school attendance and exogamy increased, the deaf population waned and the use of signing with it. In the Negev desert many hearing individuals in the 3,500-strong Bedouin Al-Sayyid community use sign language to communicate with about 150 congenitally deaf family members. Al-Sayyid is "an isolated endogamous community with a high incidence of nonsyndromic, genetically recessive, profound prelingual neurosensory deafness." (Sandler, Meir, Padden \& Aronoff, 2005). In Bengkala on the island of Bali, a village with "close intermarriage", most of the 2,700 population are fluent in Kata Kolok, the local sign language used by 40 or so congenitally deaf individuals (Branson, Miller, Marsaja \& Negara, 1996; Marsaja, 2008). The village of Alipur in India is an endogamous Shia Muslim enclave in an otherwise Hindu area. Many of the 20,000 hearing population are able to use the local sign language to communicate with the 150 or so congenitally deaf members of the community (Panda, 2012). In Adamorobe in eastern Ghana, sign language was used by about 30 deaf and 1,400 hearing people. This community also has an unusually high incidence of genetically recessive deafness, affecting around $2 \%$ of the population and possibly a much higher proportion in the past (Nyst, 2007; Kusters, 2012). Pasa kidd is a sign language used by about 2,000 people in the villages around Ban Khor in northeast Thailand, in some of which 1 in 100 people are congenitally deaf (Nonaka, 2004, 2012). Inuit Sign Language is used by both the deaf (about 50 people) and some of the hearing (about 100 people) in Inuit communities in the Canadian Arctic. In this area the incidence of hereditary deafness is reported to be up to six times that in southern Canada (Schuit, 2012). It seems clear these cases all have two key (interconnected) features in common: cultural and/ or geographical isolation supporting explicit or de facto endogamy and a high proportion of community members with hereditary sensorineural deafness. The latter are of sufficient critical mass to develop their own sign language and their hearing friends and relatives learn it with varying degrees of proficiency.

The Australian situation, however, is somewhat different. Many indigenous communities in Australia still use sign language as an everyday form of communication and it is probable that such languages existed all over the continent before the time of European contact (Roth, 1897; Strehlow, 1915; Warner, 1937; Mountford, 1938, 1949; Berndt, 1940; Love, 1941). In contrast to the village sign languages discussed above, these are 'alternate' sign languages, which are used by people who also use one or more spoken languages (Kendon, 1988; Wilkins, 1997; Green, 2009). Thus, unlike primary sign languages, Australian sign languages mirror the spoken form to a large extent and may be used in conjunction with it.

There are a number of obvious and oft-quoted situations in traditional Aboriginal society where sign language predominates. The best known of these is ceremonial speech taboo, of which the two main examples are restrictions imposed on widows and female kin in mourning and on young men undergoing initiation. It has also often been observed that signing is commonly used out bush, either as a means of silent communication when hunting, or to complement spoken language between people who are a great distance apart. However, the use of sign in many communities is much more pervasive and much more subtle than these observations would suggest. Kendon (1991) remarks that 
"although speech taboos may account for the complexity of signing in some areas, this must be understood as but a special elaboration within the context of a more general predisposition to use sign that seems to be widespread in Aboriginal society." (p.144)

And, according to Green, Woods \& Foley (2011), in central Australian communities,

"Even in situations where it could be argued that sign is redundant to accompanying speech, it is nevertheless omnipresent. Sign is used in everyday conversation for particular cultural and pragmatic reasons, and a switch to sign may signal the circumspection required of certain topics". (p.68)

Thus, in these communities anyone may use sign either to complement spoken communication or to replace it when it is socially inappropriate. Naturally, for some hearing impaired individuals in these communities sign is the primary mode of communication. For hearing individuals, sign may be used simply in place of greetings or small talk between friends, but may also be used to show respect or deference in certain social situations. Among such situations identified by Kwek (1991) are initial interactions with strangers (especially before kinship relations have been established), by young people to old people and by shy individuals in general. In Kwek's opinion, signing may perhaps be seen as somehow "off the social record". She has also observed the use of signing to conduct conversations parallel to spoken communication at group meetings. All in all, Kendon's (1988) conclusion is that, while the origins of Aboriginal sign languages may be unclear, the cultural environment of Aboriginal society has facilitated their development and retention:

"if people, for whatever reason, resort to signs as a means of communication, if the society they live in conducts interaction in the [Aboriginal] way...the practice of using signs will be favoured, and may spread"

This suggests that Aboriginal culture was already predisposed to accommodate the use of signing and that all that was needed was some kind of trigger to initiate its development. The question then is: what might that trigger have been?

\section{Hearing Impairment in the Australian Aboriginal Population}

Within a few weeks of birth the majority of Aboriginal infants develop chronic otitis media with effusion (OME). Over the years various studies have found prevalence rates of OME of between $10 \%$ and $54 \%$ in Aboriginal schoolchildren (Coates, Morris, Leach, \& Couzos, 2002). These are by far the highest rates in the world (Acuin 2004, p.14ff), with up to $36 \%$ of cases having perforations of the eardrum (Coates et al, 2002). Studies have shown that $50-70 \%$ of Aboriginal children have a significant hearing loss (i.e. greater than $25 \mathrm{~dB}$ ). This compares with $0.26 \%$ of the mainstream population under 14 years (Access Economics, 2006). The disease persists throughout childhood and into adolescence and adulthood. It has been estimated that Aboriginal people spend nearly 32 months with middle ear infections between the ages of 2 and 20 years, whereas the equivalent figure for the non-Aboriginal population is 3 months (Couzos, Metcalf \& Murray, 2001). Ear infections typically cause a mild or moderate conductive hearing loss, and chronic disease causes chronic (even permanent) hearing loss. This commonly affects both the low frequency end of the scale (under $500 \mathrm{~Hz}$ ) and the upper end of the scale (above $4000 \mathrm{~Hz}$ ). Over a period of years, Linnett Sánchez and colleagues measured the hearing of more than 900 children in the Anangu Pitjantjatjara-Yankuntjatjara (APY) Lands of north-western South 
Australia (Sánchez et al 2010). Using pure tone audiometry at four frequencies, they found that at a pure tone average threshold of $25 \mathrm{dBHL}, 61 \%$ of children failed in one or both ears. The mean PTA (pure-tone audiometry) in "failing ears" was 29.6 dBHL. More recently Stoakes, Butcher, Fletcher \& Tabain (2011) tested a much smaller group of children ( $n=74)$ at Galiwin'ku on Elcho Island in the Northern Territory, using 6 pure tone frequencies. At a pure tone average threshold of $25 \mathrm{dBHL}, 70 \%$ of children failed in one or both ears, with a mean PTA in "failing ears" of $35.0 \mathrm{dBHL}$. The results of these two studies are compared in Figure 1.

Figure 1: Audiometric data from two Australian Aboriginal population groups: APY Lands = Pitjantjatjara speakers from north-western South Australia; Elcho Island = Yolnu Matha speakers from Galiwin'ku, Northern Territory

\section{Mean for pass/fail at $-25 \mathrm{~dB}$}

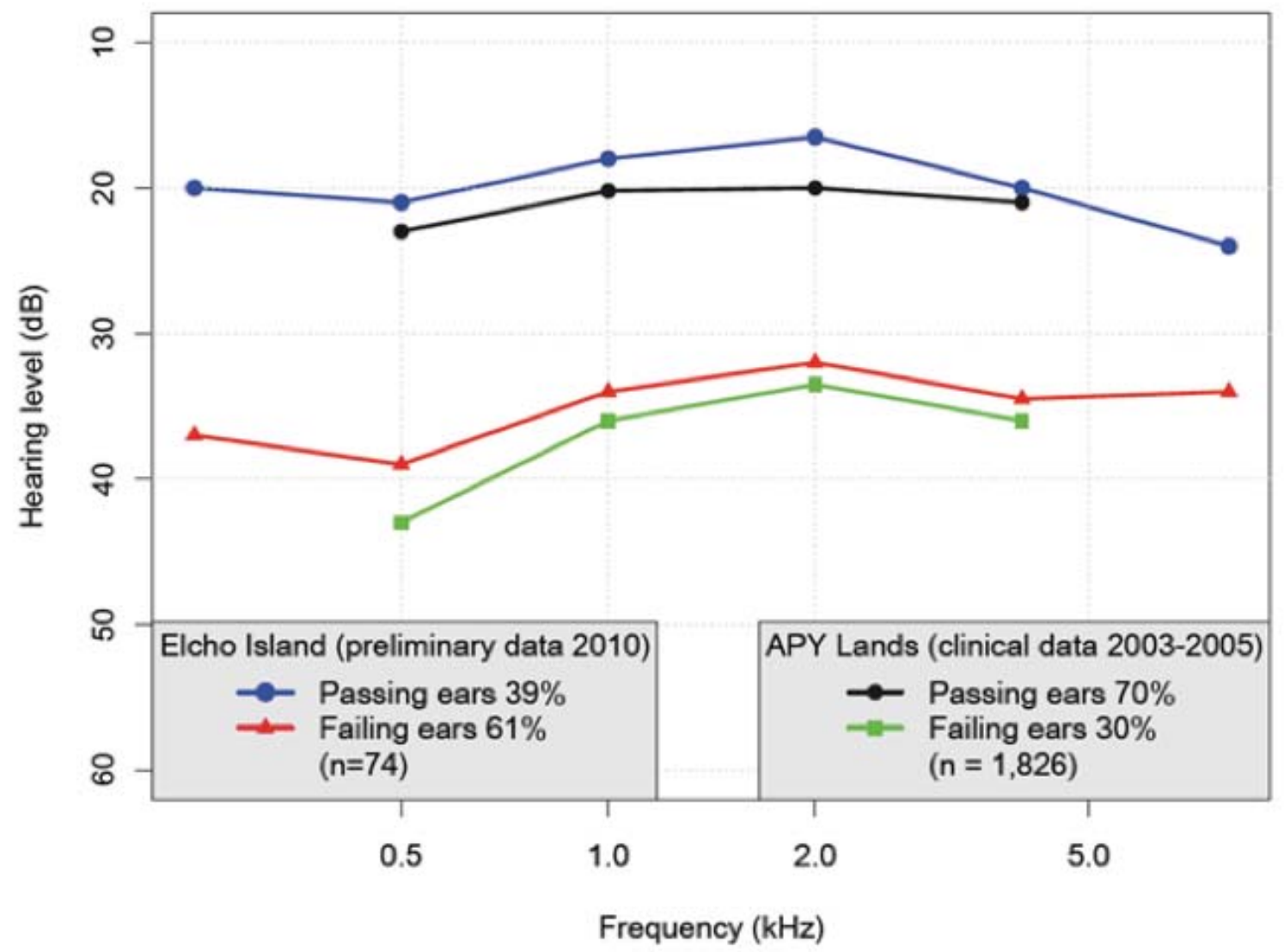

Source: Stoakes, Butcher, Fletcher \& Tabain, 2011

In the course of the NT Emergency Response (aka "The Intervention") from July 2007 to June 2012 over 10,000 children in the Northern Territory were given an "initial health check" and over half of these then received an audiology or ENT (ears, nose and throat) service. Of the latter group, $66.7 \%$ were found to have at least one type of middle ear condition and $51.4 \%$ had a hearing loss of more than $16 \mathrm{~dB}$ (Australian Institute of Health and Welfare, 2012).

It has long been recognised that, because the onset of OM-induced hearing loss occurs in the first two years of life, normal speech and language development may be disrupted (Lowell 1994, 1995; Aithal, Yonovitz \& Aithal, 2008; Williams \& Jacobs, 2009), leading to significant communication, academic, social and economic life consequences (Stenton, 2003). There is also the possibility of alteration to the temporal properties of synapses and spikes in the auditory cortex, which may contribute to permanent auditory processing deficits (Xu, Kotak 
\& Sanes, 2007). Clearly mild-to-moderate hearing loss is very widespread in the Aboriginal population, but has it been present for long enough to have been a causal factor in the rise of Aboriginal sign languages?

\section{Evidence for the antiquity of otitis media in Australia}

\section{Written and oral accounts}

We have no direct evidence relating to the middle-ear health of Aboriginal Australians prior to 1788 , but we have at least one contemporary reference to the widespread presence of chronic upper respiratory tract infection at the time of first contact. George Worgan, ship's surgeon with the First Fleet, in his journal for 24 May 1788, calls attention to "the constant Appearance of the excrementitious Matters of the Nose which is collected on the upper Lip, in rich Clusters of dry Bubbles, and is kept up by fresh Drippings" (Worgan 1788/2003, p. 36).

There are also a number of later accounts of first contact with people still leading the nomadic life suggesting widespread chronic ear infection has a long history in Aboriginal Australia. At Ernabella Mission in north-western South Australia, for example, Barbara Sayers (personal communication, 14 Aug 2012) remembers "children coming in out of the desert with no English and no clothes had shocking ears - discharge running halfway down their bodies in some cases". And Hilliard $(1968,135)$ confirms that in the early days at Ernabella "[r]unning ears were still accepted as being normal problems of childhood. Eyes and ears are still major trouble spots, some small children suffering from chronic bad ears, pouring pus, for several years. Occasionally adults continue to be so troubled." Similarly Levitt (1981, p. 54, pp. 143-44, plate 91) comments that on Groote Eylandt "infected ears were common". So common were they in fact that all over Australia various traditional remedies and healing methods evolved. In the Western Desert, for example, "they would pour breast milk into sore ears. Then maggots and pus would come out." (Glass \& Hackett, 2003, p. 316). Often the local healer would be called upon: Dobson (2007, p 18) recalls "When I was a child with those very bad ears, deaf as a doornail, the pus and muck running out of my ears, old mame-mame Penangke would help heal them".

It seems clear from these accounts that chronic suppurative otitis media has been a part of life in Aboriginal Australia for at least the past two-and-a-quarter centuries. Evidence for its presence in the population before this is, however, somewhat scant and indirect.

\section{Paleopathology}

Evidence from skeletal remains is, of course, only apparent if the disease in question affects the bone; as most infections involve soft tissue, skeletal residua are comparatively rare. Chronic suppurative otitis media, or rather complications arising from it, can potentially give rise to such residua in a number of ways.

One possibility is bone erosion. Moodie (1931, p. 52 and Plate XXXVII) claimed to have found evidence of otitis media in pre-Columbian Peruvian mummies, whereby "the external auditory meatus is greatly enlarged by the discharge of pus". A search of the subsequent literature provides no verification of a direct causal link between middle ear discharge and ear canal size. However, chronic negative middle ear pressure and retraction of the tympanic membrane caused by otitis media may lead to the keratinisation of epithelial cells (dead skin) in the upper part of the middle ear (epitympanum), forming a mass known as a cholesteatoma. In about $25 \%$ of cases, this leads to erosion or absorption of the ossicles of the middle ear - particularly the incus. Evidence of such damage in medieval Danish skeletons has been reported by Qvist \& 
Grøntved (2001). In other cases the mastoid bone in Native American skeletons has been found to be eroded by chronic infection (Gregg \& Gregg 1987). Cholesteatomata may also erode through the roof of the middle ear (intracranially), leading to meningitis and brain abscesses (Mann 1992). However, no evidence of such pathology has been reported in Aboriginal skeletons.

A second possible indication is changes in mastoid air cell patterns. The mastoid portion of the temporal bone is diploic (semi-solid) until just before birth and only becomes pneumatised (porous) by subsequent ingrowth of the mucous membrane from the middle ear. The air cell system is usually developed by 4-5 years of age, but pneumatisation continues until the teens. Chronic otitis media is known to inhibit this process. Thus Gregg \& Gregg (1987) suggest the degree and pattern of pneumatisation visible on mastoid radiographs of Native American skulls not only provide evidence of the presence of otitis media, but also give a rough indication as to the point in life at which it occurred. Pneumatic well-formed air cells suggest no adverse effect of otitis media; a diploic mastoid bone (with no pneumatisation) suggests inhibition early in life; mixed development suggests the presence of otitis media during pneumatisation. There have been no comparable studies of Australian Aboriginal skeletons.

Finally, aural exostoses are sessile (broad based) bony projections in the inner portion of the external auditory canal. These are caused by the retention of fluid in this area, most commonly through failure to dry the ears after swimming or surfing. However, there is also the possibility they may be caused by transudation (seeping) of fluid from an infected middle ear. Roche (1964) states "The etiology of aural exostoses has not been established with certainty. Some, but not all, develop in association with chronic suppurative otitis media". He examined 476 skulls of deceased Aboriginal people obtained from the Murray Black collection. Whilst it is probable that many of these were over 10,000 years old, it was not possible to determine which examples were pre-European contact and which were post-contact. Roche found that $28 \%$ of skulls had aural exostoses and concluded "The incidence of exostoses in these Australian aboriginal skulls is the highest that has been reported for any group except the American Indian skulls excavated in Kentucky".

It is, of course, no longer considered culturally appropriate for such examinations to be carried out. Thus it is unlikely further paleopathological evidence concerning the antiquity of otitis media in Aboriginal Australians will be forthcoming.

\section{Evidence for a susceptibility to otitis media in Aboriginal Australians}

Genetic analysis is a more promising area for the future; although at the time of writing there have been fewer than 40 scientific papers in this area relating to Australian indigenous populations, there are indications this situation is gradually changing (Kowal \& Anderson, 2012). It is no longer a matter of debate that a strong genetic component is involved in predisposition to both recurrent acute otitis media and chronic otitis media with effusion. Whilst the genetics are no doubt complex, with a number of genes contributing to the overall phenotype, there is significant evidence from epidemiological and molecular biological studies that susceptibility to these versions of the disease is largely genetically determined. A major study by Casselbrant and colleagues, for example, followed a cohort of 168 same-sex twin and triplet sets over 5 years (Casselbrant et al, 1999; 2004). They found that after 2 years the estimated heritability of amount of time spent with otitis media with effusion was $73 \%$ - an effect which attenuated after the $3^{\text {rd }}$ year, but remained significant after 5 years. More recently Hafrén et al (2011) studied 901 subjects with recurrent acute otitis media and 559 with chronic otitis media with effusion. Their heritability estimates were $38.5 \%$ for the recurrent form of the disease, $22.1 \%$ for the chronic form and $47.8 \%$ for otitis media of any kind. 
Genetic mutations (single-nucleotide polymorphisms or SNPs) implicated in otitis media have been identified in a number of human genes. The strongest candidate to date is probably the F-box gene FBXO11, located on chromosome 2 (Hardisty-Hughes et al, 2006; Tateossian et al, 2009), which is expressed in middle ear basal epithelial cells in late embryonic stages and early infancy, when inflammatory changes are under way. The association of FBXO11 mutations with severe otitis media has subsequently been confirmed by Rye et al (2011), using family-based association testing in an analysis of 434 families (561 affected individuals) from the Western Australian Family Study of otitis media. The association was replicated by directed analysis of data for a further 253 cases and 866 controls from the Western Australian Pregnancy Cohort Study. More recently in a genome-wide association study Allen et al (2013) genotyped 602 subjects from 143 families with 373 otitis media subjects and replicated an association with chromosome 2, but at a different gene location. This and other similar studies (e.g. Casselbrant et al 2009), have also identified a number of other possible candidates. To date no such studies have been carried out on Australian Aboriginal subjects.

As McEvoy et al (2010) put it: "Australia has been the subject of relatively few DNA studies even though understanding regional variation in genomic structure and diversity will be important if disease-association mapping methods are to be successfully evaluated and applied across populations." A small number of studies have analysed the genetic affiliations and possible migration history of the Australian Aboriginal population and reached conflicting conclusions. In one of the first such studies, Roychoudhury (1984) used gene frequency data to investigate the possibility of a genetic relationship between southern Indian and Sri Lankan tribes and the aboriginal populations of Malaya, New Guinea and Australia. He found "no... evidence to suggest that Indian tribes and Australian Aboriginals are biologically related". Redd and colleagues (Redd \& Stoneking 1999; Redd et al 2002) studied nucleotide variation in mt (mitochondrial) DNA and also SNPs and STRs (short tandem repeats) on the Y chromosome. Their results separate PNG highland and Aboriginal Australian populations (about 40,000 years ago) and link Aboriginal Australian populations with populations from the subcontinent of India, suggesting a more recent wave of migration (less than 4,000 years ago).

Subsequent work has presented evidence against such a link and suggested Australia was populated by a single wave of migration. Hudjashov et al (2007) analysed mtDNA and $Y$ chromosome variation in Aboriginal Australians and Melanesians and compared the resulting profiles with global data, concluding all Australian lineages fell within the mitochondrial founder branches associated with the exodus of modern humans from Africa 50-70,000 years ago. They detected only minor secondary gene flow into Australia, which could have taken place before the land bridge between Australia and New Guinea was submerged 8,000 years ago. Kumar et al (2009) sequenced 966-mitochondrial genomes from 26 relic tribes of India and claimed to show a shared mtDNA lineage between Indians and Australian Aborigines providing direct genetic evidence of "an early colonization of Australia through south Asia, following the 'southern route'". In a genome-wide investigation of Australian Aboriginal SNP diversity in a sample of participants from the Riverina region McEvoy et al (2010) found that, whereas there was a deep common origin with Papuan New Guineans and Melanesians, there was little evidence of substantial later migration until the very recent arrival of European colonists. This conclusion was supported by Rasmussen et al (2011), who sequenced a genome obtained from a 100-year-old lock of hair from an Aboriginal man from Western Australia. They claimed to show the ancestors of present-day Aboriginal Australians migrated into eastern Asia 62,000 to 75,000 years ago and the Australian genome clustered together with those of Highland PNG and Bougainville, with the next closest populations being the Munda speakers of India and the Aeta from the Philippines. 
On the other hand, a more recent study by Pugach et al (2013) has revived the idea of multiple migrations. In an analysis of large-scale genotyping data, they found "an ancient association between Australia, New Guinea, and the Mamanwa (a Negrito group from the Philippines), with divergence times for these groups estimated at 36,000 years ago, ... supporting the view that these populations represent the descendants of an early "southern route" migration out of Africa", but they also detected indications of "substantial gene flow between the Indian populations and Australia" estimated to have occurred some 4,000 years ago. In this connection, it is interesting to note the prevalence of chronic otitis media in southern India is second only to that found in Aboriginal Australians (Acuin 2004). To quote McEvoy et al (2010) once more, "A broader survey of Australia, including diverse geographic sample populations, will be required to fully appreciate the continent's unique population history and consequent genetic heritage, as well as the importance of both to the understanding of health issues."

What is lacking to date is a convergence of the above two approaches in the form of a scientific study of a possible genetic susceptibility to otitis media amongst the Australian Aboriginal population. There is only one published account which compares the prevalence of chronic otitis media in different population groups within Australia. Rothstein, Heazlewood \& Fraser (2007) compared data from communities in Far North Queensland whose populations were predominantly Aboriginal, Torres Strait Islander or European (3562 children in all). The prevalence rates amongst children seen by the paediatric outreach service are shown in Figure 2. If the figures for Aboriginal children and Islander children are extrapolated to the entire population (based on 2001 census data), then the prevalences for these two groups are $14.7 \%$ and $2.9 \%$ respectively - a clear indication the Aboriginal population is far more susceptible to the disease than either of the other two groups.

Figure 2: Proportion of children with chronic suppuratives otitis media by population group in remote communities in Far North Queensland

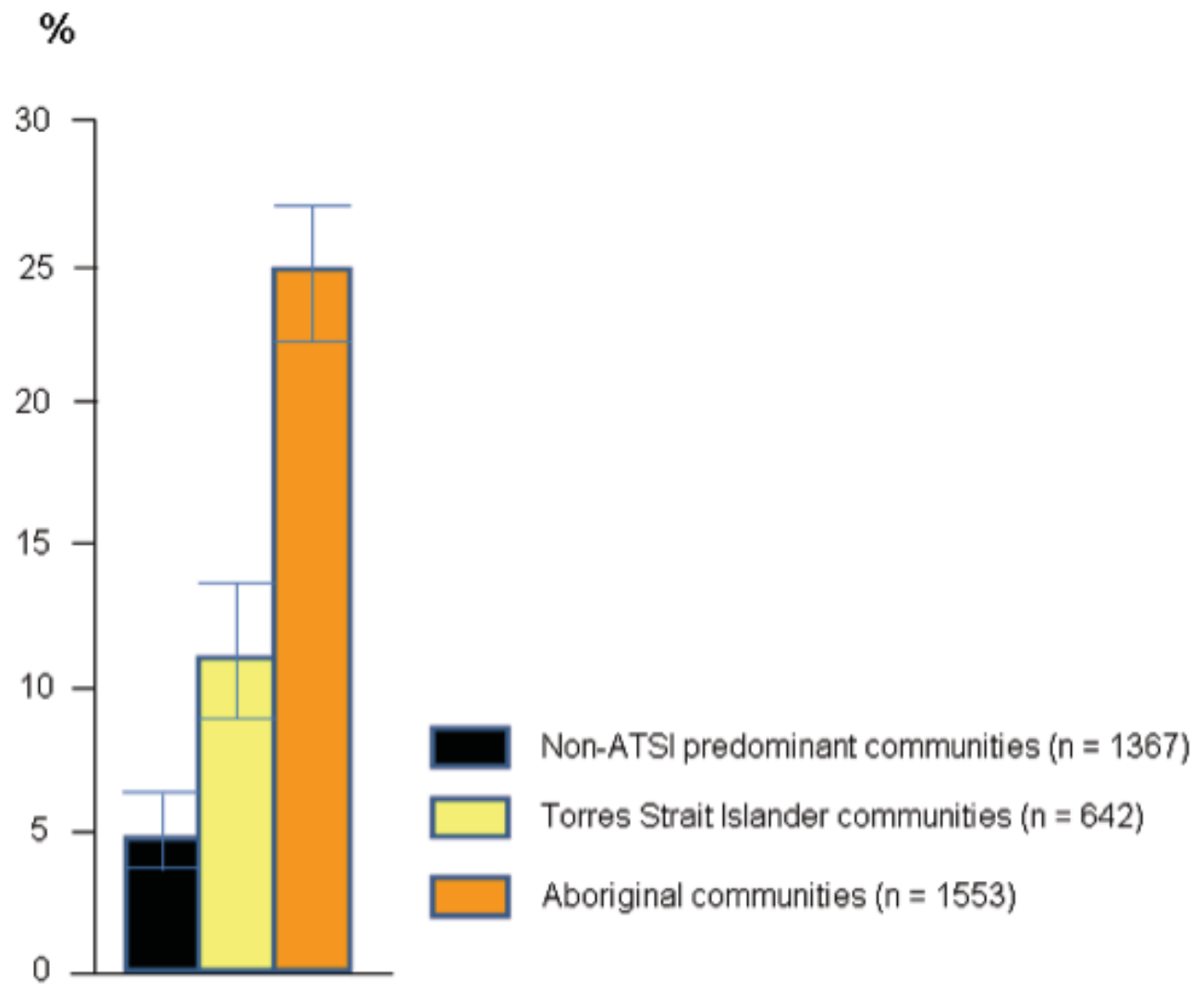

Source: Rothstein, Heazlewood \& Fraser, 2007 


\section{The possibility of a connection}

The most common reason (usually the only one) for the development of a sign language is hearing impairment in the population in question. The sign language situation in Australia is unique in that (1) sign languages probably developed amongst the entire population of the continent and (2) these sign languages were all of the alternate type - i.e. evolved to complement spoken language rather than replace it. But the Australian Aboriginal population is also unique in that it currently has the highest prevalence of otitis media and mild-to-moderate hearing loss in the world. If this is the result of a genetically determined susceptibility, then it may be of considerable antiquity. We have argued elsewhere (Butcher, 2006; Butcher, Stoakes, Fletcher \& Tabain, 2012) that the fact that the majority of this population has a different hearing profile from most of the rest of the world may account for the development of sound systems in Aboriginal languages which are different from most of the rest of the world. It is not inconceivable that alternate sign languages in Australia may have emerged for the same reason. If the majority of a given population have a mild-to-moderate hearing impairment, then it seems reasonable to surmise that they might develop an alternate sign system (as well as acoustically appropriate sound systems) in order to optimise their communication. The reason this has not happened in other parts of the world would be that there is no 'differently hearing' population of this size elsewhere in the world.

\section{Summary, Conclusions and Implications}

A number of hearing communities around the world have developed sign languages. These are without exception isolated communities with a significant minority of congenitally profoundly deaf members. The Australian Aboriginal population is unique in that it has developed alternate sign systems which are available for use by the whole community in a wide variety of social situations, possibly throughout the continent. The Australian Aboriginal population is also unique in that the majority of its members have suffered from chronic otitis media in childhood, which has led to a different hearing profile from most of the rest of the world's population. The antiquity of this situation is unknown but the possibility exists that it may even date back to the most recent migration of 4,000 B.P.; recorded observations suggest the widespread occurrence of upper respiratory tract infection since the very first days of European contact; limited paleopathological evidence reveals a high level of what may be otitis media residua in a heterogeneous sample of uncertain antiquity; epidemiological and molecular biological research show heritability estimates for susceptibility to otitis media ranging from 40 to $70 \%$. However, the majority of genes underlying this susceptibility are, as yet, unidentified and none have been studied in the Aboriginal population. Some of the limited research on Aboriginal genomics has indicated a possible connection with populations of southern India, where currently the prevalence of otitis media is the second highest in the world. One recent survey has shown that the prevalence in Aboriginal communities is double that in Torres Strait Islander communities and five times that in European communities.

Thus the Aboriginal population of Australia may well have a genetic susceptibility to otitis media. It seems certain that generations of Aboriginal people have had mild-to-moderate conductive hearing loss and therefore hear somewhat differently from the majority of the world's population. This may be what has led to (1) the evolution of unique sound systems to maximally exploit this different hearing profile, and (2) the evolution of unique alternate sign languages to augment oral communication. One possible scenario is that this situation already existed more than 4,000 years ago in southern India and that a section of the population migrated to Australia, bringing with them their dogs, their susceptibility to otitis media, their phonologies, and their alternate sign languages. 
In terms of investigating these possibilities further, one promising avenue would be to extend the search for otitis media susceptibility genes to the Aboriginal population. It would be interesting to know, for example, whether the prevalence of mutations on the FBOX11 gene is higher amongst the Aboriginal population than amongst non-Aboriginal Australians. It would also be of interest to look for evidence of alternate sign language use amongst the populations of southern India, particularly those most affected by otitis media. Most importantly of all, however, it is vitally important to document, maintain and possibly revive the sign languages of Aboriginal Australia. For by teaching Aboriginal children only in English, by paying only lip service to their traditional languages and ignoring their sign languages altogether, we may be depriving them of a form of communication which is most appropriate for their hearing profile - i.e. an oral language with a sound system optimally attuned to the typical hearing curve of an otitis media sufferer and a sign language which complements their oral language.

\section{References}

Access Economics. (2006). Listen Hear! The economic impact and cost of hearing loss in Australia. Access Economics Pty Ltd. Retrieved from https://www.audiology.asn.au/public/1/files/ Publications/ListenHearFinal.pdf.

Acuin, J. (2004). Chronic suppurative otitis media. Burden of illness and management options. Geneva: World Health Organisation Report (WHO).

Aithal, S., Yonovitz, A., \& Aithal, V. (2008). Perceptual consequences of conductive hearing loss: speech perception in indigenous students learning English as a 'school' language'. The Australian and New Zealand Journal of Audiology, 30, 1-18.

Allen, E.K., Chen, W.M., Weeks, D.E., Chen, F., Hou, X., Mattos, J.L., Mychaleckyj, J.C., Segade, F., Casselbrant, M.L., Mandel, E.M., Ferrell, R.E., Rich, S.S., Daly, K.A., \& Sale, M.M. (2013). A genome-wide association study of chronic otitis media with effusion and recurrent otitis media identifies a novel susceptibility locus on chromosome 2. Journal of the Association for Research in Otolaryngology, 14, 791-800.

Australian Institute of Health and Welfare. (2012). Northern Territory Emergency Response Child Health Check Initiative: follow-up services for oral and ear health. Canberra: Australian Institute of Health and Welfare.

Berndt, R.M. (1940). Notes on the sign-language of the Jaralde tribe of the Lower River Murray, South Australia. Transactions of the Royal Society of South Australia, 64, 267-272.

Branson, J., Miller, D., Marsaja, I.G., \& Negara, I.W. (1996). Everyone here speaks sign language too: A deaf village in Bali, Indonesia'. In C. Lucas (Ed.), Multicultural aspects of sociolinguistics in deaf communities (pp.39-57). Washington, DC: Gallaudet University Press.

Butcher, A.R. (2006). Australian Aboriginal languages: consonant-salient phonologies and the 'placeof-articulation imperative'. In J.M. Harrington \& M. Tabain (Eds.), Speech Production: Models, Phonetic Processes and Techniques (pp.187-210). New York: Psychology Press.

Butcher, A.R., Stoakes, H.M., Fletcher, J.M., \& Tabain, M. (2012). Speaking and Hearing Australian Aboriginal Languages: could hearing impairment play a role in the evolution of a sound system? 2nd International Workshop on Sound Change, Kloster Seeon, Bavaria, Germany, 2-4 May 2012.

Casselbrant, M.L., Mandel, E.M., Fall, P.A., Rockette, H.E., Kurs-Lasky, M., Bluestone, C.D., \& Ferrell, R.E. (1999). The heritability of otitis media. A twin and triplet study. Journal of the American Medical Association, 282, 2125-2130.

Casselbrant, M.L., Mandel, E.M., Rockette, H.E., Kurs-Lasky, M., Fall, P.A., Bluestone, C.D., \& Ferrell, R.E. (2004). The genetic component of middle ear disease in the first 5 years of life. Archives of Otolaryngology - Head and Neck Surgery, 130, 273-278. 
Casselbrant, M.L., Mandel, E.M., Jung, J., Ferrell, R.E., Tekely, K., Szatkiewicz, J.P., Ray, A., \& Weeks, D.E. (2009). Otitis media: a genome-wide linkage scan with evidence of susceptibility loci within the $17 q 12$ and 10q22.3 regions. BMC Medical Genetics, 10(85). Retrieved from http://www. biomedcentral.com/1471-2350/10/85.

Coates, H.L., Morris, P.S., Leach, A.J., \& Couzos, S. (2002). Otitis media in Aboriginal children: tackling a major health problem. Medical Journal of Australia, 177, 177-178.

Couzos, S., Metcalf, S., \& Murray, R.B. (2001). Systematic review of existing evidence and primary care guidelines on the management of otitis media in Aboriginal and Torres Strait Islander populations. Canberra: Office for Aboriginal and Torres Strait Islander Health, Department of Health and Aged Care.

Dobson, V.P. (2007). Arelhe-Kenhe Merrethene - Arrernte Traditional Healing. Alice Springs: IAD Press.

Glass, A., \& Hackett, D. (2003). Ngaanyatjarra and Ngaatjatjarra to English dictionary. Alice Springs: IAD Press.

Grace, N. (1985). Everyone here spoke sign language: Hereditary deafness on Martha's Vineyard. Cambridge, MA: Harvard University Press.

Green, J. (2009). Between the Earth and the Air: Multimodality in Arandic Sand Stories. PhD thesis, University of Melbourne.

Green, J., Woods, G., \& Foley, B. (2011). Looking at language: appropriate design for sign resources in remote Australian Indigenous communities. Sustainable data from digital research: Humanities perspectives on digital scholarship, University of Melbourne, 12-14 December 2011.

Gregg, J.B., \& Gregg, P.S. (1987). Dry Bones: Dakota Territory Reflected. An illustrated descriptive analysis of the health and wellbeing of previous people and cultures as is mirrored in their remnants. Sioux Falls, SD: Sioux Printing.

Hafrén, L., Kentala, E., Järvinen, T.M., Leinonen, E., Onkamo, P., Kere, J., \& Mattila, P.S. (2011). Genetic background and the risk of otitis media. International Journal of Pediatric Otorhinolaryngology, 76, 41-44.

Hardisty-Hughes, R.E., Tateossian, H., Morse, S.A., Romero, M.R., Middleton, A., Tymowska-Lalanne, Z., Hunter, A.J., Cheeseman, M., \& Brown, S.D. (2006). A mutation in the F-box gene, Fbxo11, causes otitis media in the Jeff mouse. Human Molecular Genetics, 15, 3273-3279.

Hilliard, W. (1968). The people in Between. The Pitjantjatjara People of Ernabella. London, UK: Hodder and Stoughton.

Hudjashova, G., Kivisilda, T., Underhilld, P.A., Endicotte, P., Sanchez, J.J., Lind, A.A., Sheng, P., Oefnerh, P., Renfrew, C., Villemsa, R., \& Forsterj, P. (2007). Revealing the prehistoric settlement of Australia by $\mathrm{Y}$ chromosome and mtDNA analysis. Proceedings of the National Academy of Sciences, 104(21), 8726-8730.

Kendon, A. (1988). Sign Languages of Aboriginal Australia: Cultural, Semiotic and Communicative Perspectives. Cambridge, UK: Cambridge University Press.

Kendon, A. (1991). Introductory note to Kwek J, Occasions for sign use in an Australian aboriginal community. Sign Language Studies, 71, 143-144.

Kisch, S. (2004). Negotiating (genetic) deafness in a Bedouin community'. In J.V. van Cleve (Ed.), Genetics, Disability, and Deafness (pp.148-173). Washington, DC: Gallaudet University Press.

Kisch, S. (2008). 'Deaf discourse': The social construction of deafness in a Bedouin community in the Negev. Medical Anthropology, 27, 283-313.

Kowal, E., \& Anderson, I. (2012). Genetic research in Aboriginal and Torres Strait Islander communities: continuing the conversation. Melbourne: The Lowitja Institute. 
Kumar, S., Reddy Ravuri, R., Koneru, P., Urade, B.P., Sarkar, B.N., Chandrasekar, A., \& Rao, V.R. (2009). Reconstructing Indian-Australian phylogenetic link. BMC Evolutionary Biology, 9, 173. Retrieved from http://www.biomedcentral.com/1471-2148/9/173.

Kusters, A. (2012). Adamarobe: a demographic, sociolinguistic and sociocultural profile. In U. Zeshan \& C. de Vos (Eds.), Sign Languages in Village Communities. Anthopological and Linguistic Insights (pp.347-352). Berlin: de Gruyter.

Kwek, J. (1991). Occasions for sign use in an Australian aboriginal community. Sign Language Studies, $71,143-160$.

Levitt, D. (1981). Plants and People: Aboriginal uses of Plants on Groote Eylandt. Canberra: Australian Institute of Applied Science.

Love, J.R.B. (1941). Worora kinship gestures. Transactions of the Royal Society of South Australia, $65,108-109$.

Lowell, A. (1994). Communication and learning in an Aboriginal school: the influence of conductive hearing loss. PhD thesis, University of Sydney, NSW.

Lowell, A. (1995). Communication and Learning in an Aboriginal School: The Influence of Conductive Hearing Loss. Aboriginal Child at School, 23(4), 1-7.

Mann, G.E. (1992). The identification of chronic ear disease in the dried skull. International Journal of Osteoarchaeology, 2, 19-22.

Marsaja, I.G. (2008). Desa Kolok. A deaf village and its sign language in Bali, Indonesia. Nijmegen: Ishara Press.

McEvoy, B.P., Lind, J.M., Wang, E.T., Moyzis, R.K., Visscher, P.M., van Holst Pellekaan, S.M., \& Wilton, A.N. (2010). Whole-genome genetic diversity in a sample of Australians with deep Aboriginal ancestry. The American Journal of Human Genetics, 87, 297-305.

Moodie, R.L. (1931). Roentgenologic studies of Egyptian and Peruvian mummies. Chicago, IL: Field Museum of Natural History.

Mountford, C.P. (1938). Gesture language of the Ngada tribe of the Warburton Ranges, Western Australia. Oceania, 9, 152-155.

Mountford, C.P. (1949). Gesture language of the Walpari tribe, central Australia. Transactions of the Royal Society of South Australia, 73, 100-101.

Nonaka, A.M. (2004). Sign languages - the forgotten endangered languages: lessons on the importance of remembering. Language in Society, 33(5), 737-767.

Nonaka, A.M. (2012). Language ecological change in Ban Khor, Thailand: an ethnographic case study of village sign language endangerment'. In U. Zeshan \& C. de Vos (Eds.), Sign Languages in Village Communities. Anthopological and Linguistic Insights (pp.277-312). Berlin: de Gruyter.

Nyst, V. (2007). A descriptive analysis of Adamorobe Sign Language. PhD thesis, University of Amsterdam.

Panda, S. (2012). Alipur Sign Language: a sociolinguistic and cultural profile. In U. Zeshan \& C. de Vos (Eds.), Sign Languages in Village Communities. Anthopological and Linguistic Insights (pp.353360). Berlin: de Gruyter.

Pugach, I., Delfina, F., Gunnarsdóttir, E., Kayser, M., \& Stoneking, M. (2013). Genome-wide data substantiate Holocene gene flow from India to Australia. Proceedings of the National Academy of Sciences, 110, 1803-1808.

Qvist, M. \& Grøntved, A.M. (2001). Chronic otitis media sequelae in skeletal material from medieval Denmark. The Laryngoscope, 111, 114-118. 
Rasmussen, M., Guo, X., Wang, Y., Lohmueller, K.E., Rasmussen, S., Albrechtsen, A., Skotte, L., Lindgreen, S., Metspalu, M., Jombart, T., Kivisild, T., Zhai, W., Eriksson, A., Manica, A., Orlando, L., de la Vega, F.M., Tridico, S., Metspalu, E., Nielsen, K., Ávila-Arcos, M.C., Moreno-Mayar, J.V., Muller, C., Dortch, J., Gilbert, M.T.P., Lund, O., Wesolowska, A., Karmin, M., Weinert, L.A., Wang, B., Li, J., Tai, S., Xiao, F., Hanihara, T., van Driem, G., Jha, A.R., Ricaut, F-X., de Knijff, P., Migliano, A.B., Gallego Romero, I., Kristiansen, K., Lambert, D.M., Brunak, S., Forster, P., Brinkmann, B., Nehlich, O., Bunce, M., Richards, M., Gupta, R., Bustamante, C.D., Krogh, A., Foley, R.A., Lahr, M.M., Balloux, F., Sicheritz-Pontén, T., Villems, R., Nielsen, R., Wang, J., \& Willerslev, E. (2011) An Aboriginal Australian genome reveals separate human dispersals into Asia. Science, 334, 94-98.

Redd, A.J., \& Stoneking, M. (1999). 'Peopling of Sahul: mtDNA variation in Aboriginal Australian and Papua New Guinean populations. American Journal of Human Genetics, 65, 808-828.

Redd, A.J., Roberts-Thomson, J., Karafet, T., Bamshad, M., Jorde, L.B., Naidu, J.M., Walsh, B., \& Hammer, M.F. (2002). Gene flow from the Indian subcontinent to Australia: evidence from the $Y$ chromosome. Current Biology, 12, 673-677.

Roche, A.F. (1964). Aural exostoses in Australian aboriginal skulls. Annals of Otology, Rhinology and Laryngology, 73, 83-91.

Roth, W.E. (1897). Ethnological studies among the North-West-Central Queensland Aborigines. London: Queensland Agent-Generals Information Office.

Rothstein, J., Heazlewood, R., \& Fraser, M. (2007). Health of Aboriginal and Torres Strait Islander children in remote Far North Queensland: findings of the Paediatric Outreach Service. Medical Journal of Australia, 186, 519-521.

Roychoudhury, A. K. (1984). Genetic relationship between Indian tribes and Australian Aboriginals. Human Heredity, 34, 314-320.

Rye, M.S., Wiertsema, S.P., Scaman, E.S.H., Oommen, J., Sun, W., Francis, R.W., Ang, W., Pennell, C. E., Burgner, D., Richmond, P., Vijayasekaran, S., Coates, H.L., Brown, S.D., Blackwell, J.M., \& Jamieson, S.E. (2011). FBXO11, a regulator of the TGFb pathway, is associated with severe otitis media in Western Australian children. Genes and Immunity, 12, 352-359.

Sánchez, L., Turner, D., Sparrow, K., Buxton, S., Kapadia, S., Flint, S., Eckert, B., Howard, A., Iskov, Q., Loades, N. \& Loades, C. (2010). Prevalence of ear health and hearing problems in remote and indigenous school-age children. Audiology Australia XIX National Conference, Sydney, 16-19 May 2010.

Sandler, W., Meir, I., Padden, C., \& Aronoff, M. (2005). The emergence of grammar: Systematic structure in a new language. Proceedings of the National Academy of Sciences of the United States of America, 102(7), 2661-2665.

Schuit, J. (2012). Sociolinguistic profile of Inuit Sign Language. In U. Zeshan \& C. de Vos (Eds.), Sign Languages in Village Communities. Anthopological and Linguistic Insights (pp.389-394). Berlin: de Gruyter.

Stenton, J.S. (2003). The long term effects of the fluctuating conductive hearing loss caused by otitis media with effusion on learning behaviour for adolescent students. PhD dissertation, Griffith University, Queensland.

Stoakes, H.M., Butcher, A.R., Fletcher, J.M., \& Tabain, M. (2011). Long term average speech spectra in Yolngu Matha and Pitjantjatjara speaking females and males. In R. Pieraccini \& A. Colombo (Eds.), Proceedings of the 12th Annual Conference of the International Speech Communication Association (pp.1897-1900). Bonn: International Speech Communication Association.

Strehlow, C. (1915). Die Aranda -und Loritja-Stämme in Zentral-Australien, Part IV: Das soziale Leben der Aranda und Loritja, Section II. Frankfurt: Joseph Baer \& Co. 
Tateossian, H., Hardisty-Hughes, R.E., Morse, S., Romero, M.R., Hilton, H., Dean, C. \& Brown, S.D.M. (2009). Regulation of TGF-b signalling by Fbxo11, the gene mutated in the Jeff otitis media mouse mutant. BMC PathoGenetics, 2(5). Retrieved from http://www.pathogeneticsjournal.com/ content/2/1/5.

Vanderpoll, T., \& Howard, D. (2012) Massive prevalence of hearing loss among Aboriginal inmates in the Northern Territory. Indigenous Law Bulletin, 7, 3-7.

Warner, W.L. (1937). A Black Civilization. New York: Harper and Row.

Wilkins, D. (1997). Handsigns and hyperpolysemy: Exploring the cultural foundations of semantic association. In D. Tryon \& M. Walsh (Eds.), Boundary Rider. Essays in honour of Geoffrey O'Grady (pp. 413-444). Canberra: Pacific Linguistics.

Williams, C.J., \& Jacobs A.M. (2009). The impact of otitis media on cognitive and educational outcomes. Medical Journal of Australia, 191(9), S69-S72.

Worgan, G.B. (1788/2003). Journal of a First Fleet Surgeon. University of Sydney Library, Sydney. Retrieved from http://purl.library.usyd.edu.au/setis/id/worjour.

Xu, H., Kotak, V.C., \& Danes, D.H. (2007). Conductive hearing loss disrupts synaptic and spike adaptation in developing auditory cortex. The Journal of Neuroscience, 27, 9417-9426. 